\title{
The Effects of saponins from Sapindus Rarak fruit on rumen microbes and host animal growth
}

\author{
A Thalib, Y Widiawati, H Hamid, D Suherman, M Sabrani \\ Research Institute for Animal Production, PO BOX 221, Bogor 16002, Indonesia
}

The aim of this paper focuses on the effects of changes in rumen environment intervened by methanol-extracted Sapindus rarak fruit (MES) on microbial digestion and host animal bodyweight.

Completely randomized design was used. Eighteen local sheep weighting approximately $15 \mathrm{~kg}$ were divided into 3 treatment groups and each group consisted of 6 animals. All animals received a mixture of elephant and native grasses (50:50) ad libitum + concentrate $(0.5 \%$ of liveweight). The treatments as follow: (I) no additive, (II) addition of empty capsule and (III) addition capsule containing MES at level of 0.07 $\%$ of liveweight. Empty capsule and MES were given orally every 3 days. Feeding treatments were conducted for 14 weeks including 2 weekadaptation period. Rumen liquor of all animals were collected in the third week and measured for protozoa and bacteria populations, $\mathrm{pH}$, contents of lactic acid, VFA and $\mathrm{NH}_{3}-\mathrm{N}$, and ruminal digestibility. Ruminal digestion of plant materials was measured with a new laboratory procedure developed by Theodorou and Brooks (1990, Annual report AFRC Institute, Hurley, Maidenhead, UK). Daily bodyweight gain and feed conversion ratio were measured.

The results are shown in the table below. It is shown that MES eliminated the protozoa population by $57 \%$ and sequently increased bacteria population (by $69 \%$ ) in the rumen. It is in agreement with results reported previously by in vitro study (Thalib et al, 1994, IImu dan Peternakan, $7,2,17-21)$ and by Kurihara et al
(1978, J Agric Sci Camb, 90, 373-381). Increased rumen bacteria population in treatment III is assumed due to a lower predatory action of protozoa to bacteria.

Depressing effect of MES on protozoa population in the rumen is due to saponin content in MES (14,6\%). Lowered protozoa population has no effect on lactic acid and total VFA productions, and as a consequence, does not change $\mathrm{pH}$. Decreased $\mathrm{NH}_{3}-\mathrm{N}$ content caused by lowered protozoa population agree with a report of Jouany (1991, INRA, 239-261). Cumulative gas production resulting from rice straw fermented by rumen liquor from sheep fed MES-added diet (III) is increased by $13 \%$. It is a prospective effect of MES on rumen ability to degrade fibrous forages. The ingestion of bacteria by protozoa is selective (Kurihara et al, 1968, J Gen Microbiol, 51, 267-288). Hence, increased gas production for treatment III is assumed not only affected by increased bacteria population but also by changed composition of the bacterial mixture in the rumen. Compared to control (I), average daily gain of sheep fed MES-added diet (III) is increased by $44 \%$ with an improved efficiency by $28 \%$. However, the positive effects of MES on host animal bodyweight is enhanced by capsule ingredients (treatment II).

It is concluded that MES can improve ability of rumen microbes to digest plant materials. However, a study to find appropriate technique of giving MES to animal without using capsule is required.

\begin{tabular}{lccc}
\hline Measurements & I & II & III \\
\hline Rumen : & & & \\
Protozoa $\left(\times 10^{4} \mathrm{cell} / \mathrm{ml}\right)$ & $67.9^{\mathrm{b}}$ & $62.6^{\mathrm{b}}$ & $29.1^{\mathrm{a}}$ \\
Bacteria $\left(\times 10^{8} \mathrm{CFu} / \mathrm{ml}\right)$ & $24.0^{\mathrm{a}}$ & $23.5^{\mathrm{a}}$ & $40.6^{\mathrm{b}}$ \\
pH & 6.74 & 6.76 & 6.72 \\
Lactic acid $(\mathrm{mg} / \mathrm{ml})$ & 0.11 & 0.14 & 0.12 \\
Total VFA (mg/ml) & 5.23 & 5.30 & 5.20 \\
$\mathrm{NH}_{3}-\mathrm{N}(\mathrm{mg} / \mathrm{l})$ & $50.92^{\mathrm{b}}$ & $51.94^{\mathrm{b}}$ & $36.61^{\mathrm{a}}$ \\
Cumulative gas production $(\mathrm{ml})$ & $165^{\mathrm{a}}$ & $166^{\mathrm{a}}$ & $187^{\mathrm{b}}$ \\
Host animal bodyweight : & & & \\
Average daily gain $(\mathrm{g})$ & $38.10^{\mathrm{a}}$ & $44.76^{\mathrm{ab}}$ & $54.82^{\mathrm{b}}$ \\
Feed conversion ratio & $33.73^{\mathrm{b}}$ & $29.56^{\mathrm{ab}}$ & $24.22^{\mathrm{a}}$ \\
\hline
\end{tabular}

